\title{
Implications of Voluntary Communication Based on Gender, Education Level and Cultural Issues in an Online Environment
}

\author{
Vicki L. Gregory and Kiersten Cox \\ School of Information, University of South Florida, \\ Tampa, Florida USA
}

\author{
gregory@usf.edu cox@usf.edu
}

\begin{abstract}
Because of the method(s) of communication in a particular class, gender and cultural differences can lead to a different mix of voluntary communication in the online or blended class setting from that of a traditional classroom. Given the hybrid nature of courses taught by the School of Information at the University of South Florida, a comparison can be made among the same students in class using different methods of class communication. Comparisons between graduate, undergraduate and student-athletes in School of Information courses can also be made. This paper examines the differences experienced by students of varying cultural backgrounds in their willingness to participate in class discussion depending upon the type or types of communication media used and will discuss the implications for effective course design.
\end{abstract}

Keywords: Distance Education, Electronic Communication, Gender-based Communication Preferences

\section{Introduction}

The rapidly changing requirements in the educational curriculum of school of library and information science resulting from the exponential expansion of computer-based technologies naturally result in a reexamination of the knowledge and skills that need to be acquired by the next wave of library and information professionals. Skills in the use of new technologies are not only important in professional work but in the education process itself as more and more Library and Information Science (LIS) courses are being offered via web with faculty and students utilizing course management software. To effectively use the course management software, the instructor must take into account the learning styles and preferences of the students without some of the hints that face-to-face instructors receive in a traditional classroom.

This is a qualitative study in social informatics, with a focus on education level and gender on a

Material published as part of this publication, either on-line or in print, is copyrighted by the Informing Science Institute. Permission to make digital or paper copy of part or all of these works for personal or classroom use is granted without fee provided that the copies are not made or distributed for profit or commercial advantage AND that copies 1) bear this notice in full and 2) give the full citation on the first page. It is permissible to abstract these works so long as credit is given. To copy in all other cases or to republish or to post on a server or to redistribute to lists requires specific permission and payment of a fee. Contact Publisher@InformingScience.org to request redistribution permission. student's use of voluntary communication technology. Social informatics was defined by Kling (2000, p. 218) the "interdisciplinary study of the design, uses, and consequences of information technologies that take into account their interaction with institutional and cultural context." Kling (1999) identified social informatics key themes as the importance of social contexts and work processes, socio-technical networks, 
public access to information, and social infrastructures for computing support. Our research can also be said to be in the feminist approach to social studies in technology because of our findings in earlier research of very different patterns of communication preferences and patterns for male and female graduate students in LIS. Early feminist research into gender and technology usually followed a simplistic "social impacts of technology" approach (Wajcman, 2000). However, many changes have occurred since 2000 in the research into gender and technology. This line of research is now looking at the power structure surrounding technology in terms of its design and use (Wajcman 2010). The traditional view of technology being associated with men and not women is being challenged with an emphasis on the gender differences in the needs for technology and its use.

\section{Literature Review of Gender and Cultural Differences in Communication}

The underlying social meaning of communication is imbued with culture, but cultural misunderstanding often occurs when communicating with a member of the opposite gender as well as from cross-cultural communication. (Gefen and Ridings, 2005)

Although speaking what may seem on the surface as the same language, men and women unconsciously insert gender-specific social messages. (Herring, 2000; Tannen, 1994). That can be over simplified to the statement that men and women are not really speaking the same language. It is the basic premise of sociologists that communication is interpreted through the prisms of culture, and that these cultural lenses apply to men and women just as they apply across cultures. (Yates, 1996, 1997).

One of the prominent gender-based cultural differences in language is that during oral discourse men, more than women, communicate to establish social standing, control the conversation, and exchange information, while women, more than men, communicate to create rapport (Tannen, 1994; and Tannen, 1995). Research has also shown that, at least to some extent, these crosscultural misunderstandings between women and men carry over to electronic media in discussion lists. (Herring, 1996).

Burnett's (2000) research identifies a number of online information behaviors in virtual communities and categorizes them in terms of the author's intent. A number of these categories are useful for analyzing the content of student communications in an online or blended or hybrid class setting. His categories have two top-level domains, "non-interactive (lurking)" and "interactive." For this study we are only interested in the interactive categories. He further breaks down the interactive domain into the categories of "hostile" and "collaborative." The "hostile" category includes flaming, trolling, spamming, and cyber-rape. The "collaborative" category is further broken down into the subcategories of "non-information specific" and "information specific." The non-information specific activities are broken down into "neutral" - pleasantries/gossip, "humorous" - language games/play, and "empathic" - emotional support. The information specific activities are broken down into "announcements," "queries/specific requests," and "directed group projects." These categories appear to work well in the analysis of student responses on the voluntary electronic communications made by our students as all their communications can easily be placed into his categorizations.

In the words of Nancy Van House (2004, p. 45),

Any technology is defined only relationally, in use, by people's understandings, interpretations, and practices, including how they fold a given technology into their ongoing practices and materials. Howev- 
er, technology also helps to (re)define the group, in a recursive, mutu-

al process. Technology and the social are co-constituted.

The authors' initial research into student communication patterns in required weekly discussion boards looked at gender, minority status and age and only used two categories when doing the content analysis: dominant and supportive messages (see Tables 1 and 2). Dominant messages were determined by tone and length. Supportive messages were ones agreeing with another student, encouraging another student and generally short. It is important to note that messages are categorized, not the student. Both male and females posted messages that were dominating (in tone and length) and supportive (agreeing with another poster, encouraging, but generally short). However, females were more likely to post supportive messages. The analysis of the Text Only Blackboard Discussion Board postings from one LIS class, LIS5404, offered some interesting patterns, or lack thereof. Whereas the research asserts that males tend to dominate discussion forums in web-based environments, this analysis did not support that assertion. To the contrary, females dominated the discussion forums in all aspects -- they had the highest number of postings, the longest and most thorough postings. (But, as in most LIS classes, women made up the majority of the enrolment.) In terms of the technology text versus VoIP, males were more likely to dominate the text and voice chat than the females as a percentage of the messages taking into effect the ratio of males to females. In the voice chat, one male contributed most of the supportive messages while the supportive messages from females included at least one from every female student. In addition to gender, the data suggest that there may be racial and cultural differences that need to be taken into account when designing the communications aspects of a class.

Table 1: Categorization of Messages by Male LIS Masters' Students

\begin{tabular}{|l|l|l|l|l|l|}
\hline $\begin{array}{l}\text { Number } \\
\text { of -- }\end{array}$ & $\begin{array}{l}\text { White } \\
\text { Male }\end{array}$ & $\begin{array}{l}\text { Minority } \\
\text { Male }\end{array}$ & $\begin{array}{l}\text { Total } \\
\text { Male }\end{array}$ & $\begin{array}{l}\text { Dominant } \\
\text { Messages }\end{array}$ & $\begin{array}{l}\text { Supportive } \\
\text { Messages }\end{array}$ \\
\hline Students & 12 & 4 & 16 & NA & NA \\
\hline Postings & 167 & 185 & 352 & 302 & 50 \\
\hline $\begin{array}{l}\text { Text Chat } \\
\text { Messages }\end{array}$ & 27 & 19 & 46 & 29 & 17 \\
\hline $\begin{array}{l}\text { Voice Chat } \\
\text { Messages }\end{array}$ & 30 & 10 & 40 & 35 & 5 \\
\hline
\end{tabular}


Table 2: Categorization of Messages by Female LIS Masters' Students

\begin{tabular}{|l|l|l|l|l|l|}
\hline $\begin{array}{l}\text { Number } \\
\text { of --- }\end{array}$ & $\begin{array}{l}\text { White } \\
\text { Female }\end{array}$ & $\begin{array}{l}\text { Minority } \\
\text { Female }\end{array}$ & $\begin{array}{l}\text { Total } \\
\text { Female }\end{array}$ & $\begin{array}{l}\text { Dominant } \\
\text { Messages }\end{array}$ & $\begin{array}{l}\text { Supportive } \\
\text { Messages }\end{array}$ \\
\hline Students & 43 & 25 & 68 & NA & NA \\
\hline Postings & 487 & 265 & 752 & 473 & 308 \\
\hline $\begin{array}{l}\text { Text Chat } \\
\text { Messages }\end{array}$ & 20 & 2 & 22 & 4 & 18 \\
\hline $\begin{array}{l}\text { Voice Chat } \\
\text { Messages }\end{array}$ & 40 & 12 & 52 & 10 & 42 \\
\hline
\end{tabular}

\section{Methodology}

It should be emphasized that this is ongoing research that the authors have been pursuing this subject for about 5 years now utilizing content analysis in pursuit of a grounded theory as to why and under what circumstances these communication patterns emerge. Numerous examples of the types of communication patterns that were originally found in 2007 continue with undergraduates and graduates students in our own classes and in the professional literature and in conversations with faculty from other schools and disciplines inside and outside the US to realize that these patterns are occurring in other universities as well our own. Once this research project is completed, it is time to move to a much wider and scientific sample to test the concepts and grounded theory that we have found within our own classes in a much broader sample. The research questions for this study were:

1. Are male and female student styles of information postings the same in voluntary settings as in the required postings for the class?

2. Does the pattern for undergraduate students (regular and athletes) differ from the patterns we have found in graduate classes?

\section{Analysis of Graduate LIS Students}

The voluntary postings were compared to the required postings for a 4-week period. The results for the undergraduate classes were somewhat different than for the graduate students, so they are separated in the analysis. This class represented in Table 3 is a first or very early course in the master's curriculum, and students' postings show some of the same characteristics of the undergraduate classes (see below). Some very chatty early messages by females seemed to have driven the males away from postings in the voluntary discussion board. 
Table 3: Voluntary Postings Compared to Required Postings from an Early Course in the LIS Master's Curriculum. There were 8 males and 11 females in this class.

\begin{tabular}{|c|c|c|c|c|c|}
\hline $\begin{array}{l}\text { Discussion } \\
\text { Board }\end{array}$ & $\begin{array}{l}\text { Voluntary } \\
\text { Male }\end{array}$ & $\begin{array}{l}\text { Voluntary } \\
\text { Female }\end{array}$ & $\begin{array}{c}\text { Required } \\
\text { Male }\end{array}$ & $\begin{array}{l}\text { Required Fe- } \\
\text { male }\end{array}$ & Total \\
\hline $\begin{array}{l}\text { Hostile Posts - } \\
\text { Flaming }\end{array}$ & 0 & 4 & 0 & 1 & 5 \\
\hline $\begin{array}{l}\text { Non-information } \\
\text { Specific } \\
\text { Pleasantries, } \\
\text { Humor, etc. }\end{array}$ & 0 & 12 & 5 & 0 & 17 \\
\hline $\begin{array}{l}\text { Supportive or } \\
\text { Empathic }\end{array}$ & 0 & 5 & 5 & 45 & 55 \\
\hline Announcements & 0 & 5 & 0 & 1 & 6 \\
\hline $\begin{array}{l}\text { Queries \& Re- } \\
\text { sponses }\end{array}$ & 2 & 14 & 53 & 78 & 147 \\
\hline $\begin{array}{l}\text { Directed Group } \\
\text { Projects }\end{array}$ & 0 & 0 & 0 & 0 & 0 \\
\hline \multicolumn{6}{|l|}{ Social Media } \\
\hline $\begin{array}{l}\text { Hostile Posts- } \\
\text { Flaming }\end{array}$ & 0 & 0 & 0 & 0 & 0 \\
\hline $\begin{array}{l}\text { Non-Information } \\
\text { Specific }\end{array}$ & 0 & 18 & NA & NA & 18 \\
\hline \multicolumn{6}{|l|}{$\begin{array}{l}\text { Information } \\
\text { Specific }\end{array}$} \\
\hline Announcements & 0 & 5 & NA & NA & 5 \\
\hline $\begin{array}{l}\text { Queries and Re- } \\
\text { sponses }\end{array}$ & 20 & 14 & NA & NA & 34 \\
\hline TOTALS & 22 & 77 & 63 & 125 & 287 \\
\hline
\end{tabular}


Table 4: Voluntary Postings Compared to Required Postings from a Required Course Late in the LIS Master's Curriculum. There were 3 males and 21 females in this class.

\begin{tabular}{|c|c|c|c|c|c|}
\hline $\begin{array}{l}\text { Discussion } \\
\text { Board }\end{array}$ & $\begin{array}{c}\text { Voluntary } \\
\text { Male }\end{array}$ & $\begin{array}{c}\text { Voluntary } \\
\text { Female }\end{array}$ & $\begin{array}{l}\text { Required } \\
\text { Male }\end{array}$ & $\begin{array}{c}\text { Required } \\
\text { Female }\end{array}$ & Total \\
\hline $\begin{array}{l}\text { Hostile Posts - Flam- } \\
\text { ing }\end{array}$ & 0 & 0 & 0 & 0 & 0 \\
\hline $\begin{array}{l}\text { Non-information } \\
\text { Specific } \\
\text { Pleasantries, Humor, } \\
\text { etc. }\end{array}$ & 4 & 42 & 1 & 3 & 50 \\
\hline $\begin{array}{l}\text { Supportive or Em- } \\
\text { pathic }\end{array}$ & 0 & 0 & 2 & 29 & 31 \\
\hline Announcements & 0 & 2 & 2 & 2 & 6 \\
\hline $\begin{array}{l}\text { Queries \& Respons- } \\
\text { es }\end{array}$ & 1 & 13 & 21 & 111 & 146 \\
\hline $\begin{array}{l}\text { Directed Group Pro- } \\
\text { jects }\end{array}$ & 6 & 52 & NA & NA & 58 \\
\hline \multicolumn{6}{|l|}{ Social Media } \\
\hline $\begin{array}{l}\text { Hostile Posts- } \\
\text { Flaming }\end{array}$ & 0 & 0 & 0 & 0 & 0 \\
\hline $\begin{array}{l}\text { Non-Information } \\
\text { Specific }\end{array}$ & 0 & 0 & NA & NA & 0 \\
\hline \multicolumn{6}{|l|}{$\begin{array}{c}\text { Information } \\
\text { Specific }\end{array}$} \\
\hline Announcements & 0 & 0 & NA & NA & 0 \\
\hline $\begin{array}{l}\text { Queries and Re- } \\
\text { sponses }\end{array}$ & 0 & 0 & NA & NA & 0 \\
\hline TOTALS & 11 & 109 & 26 & 145 & 291 \\
\hline
\end{tabular}

As seen in Table 4, there was no participation by males in the optional social media options even though extra credit was offered for work on the class wiki. There was only one post to the class wiki by females.

\section{Conclusions from the Graduate Classes}

In the purely voluntary or for extra credit communication options, the first few posts were important as to later participation. If the females started a chatty forum or blog, the male students tended to stay away. If a male posted first with some technology or other technical information, the males tended to respond to each other and to largely ignore the postings of the females. Even those students who could have used the extra points to improve their grade would avoid the voluntary board if the posting pattern did not fit their idea of what should be there. In the same situation in the required board, males would simply post the minimum required, but given a maledominated board, the female students would begin contacting the instructor about whether they should drop the class. 


\section{Analysis of Undergraduate Information Literacy Classes}

The authors also analyzed undergraduate Text-Only Blackboard Discussion Board postings and discovered findings similar to the early graduate course postings shown in Table 3 . As with the graduate students, some very chatty early messages by females seemed to have driven the males away from postings in the voluntary discussion board. The course examined was LIS 2005, Library and Internet Research Skills, which is a basic information literacy course and a general education elective at USF. It is also a required course for some Mass Communication majors. The online version of this course exhibits a higher number of females enrolled than males. But there is a blended section of the course where the classroom is "flipped". The students read the course lecture materials and other readings on their own and complete hands-on-learning experiences in the classroom. This version of LIS 2005 has more males enrolled than females. This section of the course exhibits a different pattern of communication altogether and makes an interesting comparison to the all-online graduate and undergraduate courses

The LIS 2005 course is designed somewhat differently from the graduate courses. Most of the postings are voluntary and bear no weight on the student's grade or are worth bonus points. However, in the blended version of LIS 2005 there was one assignment where posting to the discussion board was mandatory and credit bearing. This blended section of the class has enough differences in online communication from both the other undergraduate sections and the graduate courses that it is worth a closer look. This section of the course is made up entirely of studentathletes on athletic scholarships. This group of students it has been found has not only differences in online communication but also has a noteworthy style of live in class communication. Though this paper does not focus on live communication styles the observations we made of this special group of students is so interesting and has played such a large role in the design of future courses we thought it worth mentioning.

\section{Communication patterns in the information literacy classes generally}

Three sections of regular online students were compared to four sections of student athletes in the blended class in order to have similar numbers of students.(Table 5) The findings were quite interesting. A total of 88 students participated in the student athlete courses and 98 participated in the online sections. There were 61 male and 27 female students enrolled in the student-athletes courses and 29 male and 69 females were enrolled in the online courses. In all of the courses there was an introductory discussion board with a set list of questions. (See below). In the athletes' courses the students were encourage frequently by the instructor in class to complete the introductory discussion board and 5 participation points were attached to completion. In the online courses no points are associated with the discussion board but they are used to confirm first day class attendance and is part of what ensures that the student is not dropped from the course for non-attendance.

The rates of completion are somewhat different. $29 \%$ of all students did not complete the discussion board. $27 \%$ of all females did not respond and $15 \%$ of males did not respond. When we look at the two types of courses and students things change. In the online courses 10 out of 29 males or $34 \%$ did not respond on the discussion board but in the student athletes courses only $21 \%$ or 13 out of 61 males did not respond. Females also had differing response rates. The female student athletes had similar response rates to their male counter-parts. $22 \%$ of them or 6 out of 27 did not respond. In the online courses, however, female responders were much higher with $71 \%$, or 49 out of 69 , responding to the questions. (Table 5)

The questions asked were of a "chatty" get to know each other nature. They were as follows: 
-- What is your Major?

-- What rank are you; freshman, sophomore, junior, senior etc...?

-- What do you hope to learn from this course?

-- When doing research, what is the hardest part for you?

-- When using the internet, how do you determine which sources of information are reliable?

-- How do you detect bias in information sources?

Due to our findings it is possible that just the nature of the questions is off putting for some males in the online arena.

Table 5: Total Number of Undergraduate Students by Style of Class

\begin{tabular}{|c|c|c|c|c|}
\hline & $\begin{array}{c}\text { Total Num- } \\
\text { ber of } \\
\text { Males } \\
\text { (Online } \\
\text { Classes) }\end{array}$ & $\begin{array}{c}\text { Total Num- } \\
\text { ber of Fe- } \\
\text { males (Online } \\
\text { Classes) }\end{array}$ & $\begin{array}{c}\text { Total Number } \\
\text { of Males (Ath- } \\
\text { letes) }\end{array}$ & $\begin{array}{c}\text { Total Num- } \\
\text { ber of Fe- } \\
\text { males (Ath- } \\
\text { letes) }\end{array}$ \\
\hline $\begin{array}{c}\text { Posted to Dis- } \\
\text { cussion Board }\end{array}$ & 19 & 49 & 48 & 21 \\
\hline $\begin{array}{c}\text { Did Not Post } \\
\text { to Discussion } \\
\text { Board }\end{array}$ & 10 & 20 & 13 & 6 \\
\hline Total & 29 & 69 & 61 & 27 \\
\hline
\end{tabular}

\section{History of the student-athlete course}

Five years ago, there was a confluence of changes and innovations that opened the way for an all student-athlete information literacy course at the University of South Florida. The School of Information decided to move its LIS 2005 Library and Internet Research Skills class from an all live setting to an all online setting. Athletics opened their new building, which contains a computer lab, and they hired a new Director of Academics for Athletics who renewed USF's commitment to providing the best education possible to student-athletes and the decision was made that all student-athletes deemed "at risk" would be required to take LIS 2005; it had previously been shown that student-athletes who passed this course experienced better overall GPA's and better retention rates than those who did not. The instructor tasked with creating the online version of LIS 2005 worried that student-athletes would not be successful in the online arena, and proposed a special section of the course to be taught in the athletics computer lab specifically for student-athletes. Students read the course materials online, watch the course videos and then take quizzes on the materials on their own. But they are also required to attend at least weekly one of the 2 or 3 live labs to learn to use the tools covered in the readings. This is a very unique course, at least for USF. But it is very flexible. It accommodates travel schedules and practice times, but still allows the students to have contact with the instructor and to get live assistance when needed. 


\section{Communication patterns in the student-athlete information literacy classes}

The shift in class dynamics has changed the communication patterns in the student athlete sections of LIS 2005. (Table 6) In the classroom, the African-American males dominate all conversation. Even when they apparently haven't completed the course readings, they usually remain very vocal and want to make themselves heard and acknowledged. They also appear to crave a close relationship with the instructor, sometimes seeking the instructor's attention much as they might that of a parent.

White males followed closely by white females in these sections are the next groups that dominate live class discussions. They tend to behave more like they do in regular classroom settings. They try to answer questions posed by the instructor when they know the answers and try to avoid being called on when they don't. During open discussions they tend to stay more on topic. They don't necessarily have better or more informed input than other groups.

African-American women tend to let one woman speak for them all. They interact with everyone individually but during class discussion or question answer sessions a leader is somehow picked and this leader will volunteer to answer or will have input that seems to voice the opinion of all the African-American women. Often even when another African-American woman is called upon this leader will help answer the question or will provide input in the discussion. Hispanic men and women tend not to speak up in group discussions. They tend to prefer to interact with their instructor in small groups with others either on their same sports team or who are also native Spanish speakers or in one-on-one situations.

Working on assignments seems to create unusual classroom interaction as well. Assignments are designed to be group efforts. These students are naturally accustomed to doing everything with their team-mates. Again, the white, Hispanic and African-American female students tend to work closely with their team-mates. They seek help from the instructor first and then turn to other groups in the lab if they are stuck or the instructor is working with another group. The AfricanAmerican men however, sit with each other but send one or more of their group to scout out what other groups are doing. They bring as much information and as many of the answers back to their team-mates as possible. Though they have access to their instructor in the lab student-athletes still have online discussion boards and the bonus wiki available to them. The bonus wiki was worth up to 5 bonus points which are added to the student's lowest score.

The athletes tended to divide themselves also by their sport - men that play basketball, women that play basketball, men who play football, etc. When team leaders are present, those leaders tend to become classroom leaders as well.

Table 6: Categorization of Discussion Board Posts by Undergraduate Students

\begin{tabular}{|l|c|c|c|c|c|}
\hline $\begin{array}{c}\text { Discussion Board } \\
\text { Introductory Ques- } \\
\text { tions }\end{array}$ & $\begin{array}{c}\text { Voluntary } \\
\text { Male } \\
\text { (Online } \\
\text { Classes) }\end{array}$ & $\begin{array}{c}\text { Voluntary } \\
\text { Female } \\
\text { (Online Classes) }\end{array}$ & $\begin{array}{c}\text { Required } \\
\text { Male } \\
\text { (Athletes) }\end{array}$ & $\begin{array}{c}\text { Required } \\
\text { Female } \\
\text { (Athletes) }\end{array}$ & Total \\
\hline $\begin{array}{l}\text { Information Specific } \\
\text {-"Just -the-Facts" }\end{array}$ & 17 & 23 & 33 & 13 & 86 \\
\hline $\begin{array}{l}\text { Information Specific } \\
\text {-"Chatty" }\end{array}$ & 2 & 26 & 15 & 8 & 51 \\
\hline \multicolumn{1}{|c|}{ TOTAL } & 19 & 49 & 48 & 21 & 137 \\
\hline
\end{tabular}




\section{Comparison of regular classes to classes for athletes}

Three sections of regular online students were compared to four sections of student athletes in the blended class in order to have similar numbers of students (Table 7). The findings were quite interesting. A total of 88 students participated in the student athlete courses and 98 participated in the online sections. There were 61 male and 27 female students enrolled in the student-athletes courses and 29 male and 69 females were enrolled in the online courses. In all of the courses there was an introductory discussion board with a set list of questions. (See below). In the athletes' courses the students were encourage frequently by the instructor to complete the introductory discussion board and 5 participation points were attached to completion. In the online courses no points are associated with the discussion board.

The rates of completion are somewhat different. Twenty-nine percent of all students did not complete the discussion board; $27 \%$ of all females did not respond and $15 \%$ of males did not respond. When we look at the two types of courses and students, things change. In the online courses 15 out of 29 males or $51 \%$ did not respond on the discussion board but in the student athletes courses only $21 \%$ or 13 out of 61 males did not respond. Females also had differing response rates. The female student athletes had similar response rates to their male counter-parts. Twenty-two percent of them, or 6 out of 27, did not respond. In the online courses, however, female responders were much higher with $71 \%$, or 49 out of 69 , responding to the questions.

Table 7: Categorization of Postings - Regular and Athlete

\begin{tabular}{|c|c|c|c|c|c|}
\hline Discussion Board & $\begin{array}{c}\text { Regular } \\
\text { Male }\end{array}$ & $\begin{array}{c}\text { Regular } \\
\text { Female }\end{array}$ & $\begin{array}{c}\text { Athlete } \\
\text { Male }\end{array}$ & $\begin{array}{l}\text { Athlete } \\
\text { Female }\end{array}$ & Total \\
\hline Hostile Posts - Flaming & 0 & 0 & 0 & 0 & 0 \\
\hline $\begin{array}{l}\text { Non-information Specific } \\
\text { Pleasantries, Humor, etc. }\end{array}$ & 0 & 0 & 0 & 0 & 0 \\
\hline Supportive or Empathic & 0 & 0 & 0 & 0 & 0 \\
\hline $\begin{array}{l}\text { Information Specific Re- } \\
\text { sponses Factual }\end{array}$ & 12 & 53 & 2 & 13 & 80 \\
\hline $\begin{array}{l}\text { Information Specific Re- } \\
\text { sponses Chatty }\end{array}$ & 2 & 26 & 21 & 5 & 54 \\
\hline \multicolumn{6}{|l|}{ Social Media - Wiki } \\
\hline Hostile Posts - Flaming & 1 & 0 & 0 & 0 & 1 \\
\hline $\begin{array}{l}\text { Non-information Specific } \\
\text { Pleasantries, Humor, etc. }\end{array}$ & 0 & 0 & 0 & 0 & 0 \\
\hline Supportive or Empathic & 3 & 22 & 0 & 0 & 25 \\
\hline $\begin{array}{l}\text { Information Specific Re- } \\
\text { sponses Factual }\end{array}$ & 5 & 30 & 0 & 0 & 35 \\
\hline $\begin{array}{l}\text { Information Specific Re- } \\
\text { sponses Chatty }\end{array}$ & 0 & 4 & 0 & 0 & 4 \\
\hline TOTALS & 23 & 135 & 23 & 18 & 199 \\
\hline
\end{tabular}

When categorized, the students' posts reveal more interesting data. The posts were classified as "just-the-facts" and "chatty" meaning that the students used greetings at the beginning of their posts and volunteered more information than was asked in the questions. In the online courses many more females than males posted chatty answers than their male counterparts. Twenty-six out of 69 women vs. only two men made chatty posts in the athlete's classes. 
In LIS 2005 a wiki was utilized as a bonus exercise. The students are instructed about what a wiki is and how to use one. They are directed to post information about the tools they have learned to use while taking this course or any new research tools they have discovered that they think would be helpful to others. They can earn up to 5 bonus points which are then added into their lowest score. It is actually surprising how few students choose to participate in this bonus assignment.

Some students in the online sections take advantage of this opportunity but no student-athlete has ever completed this assignment. We don't yet know why this is. All of the sections of LIS 2005 perform similarly, with grade bell curves being very similar. Just as many student athletes could use bonus points as those in the online courses. The instructor even reminds the student athletes in person about the bonus assignment. But still no one posts.

In the online sections we have noticed that women tend to post to the bonus wiki more than men and they tend to be chattier in their posts on the bonus wiki. This chattiness seems to discourage men from participating. For example in spring 2011 a number of women posted very chatty comments on the wiki which apparently was off-putting to the men in the class as one male posted before the chatty comments but none posted after the conversational posts started.

\section{Conclusions from the undergraduate classes generally}

As with the early graduate students, in the purely voluntary or for extra credit communication options, the first few posts were important as to later participation. If the females started a chatty forum or wiki, the male students tended to stay away regardless of the possibility of points. In the extra credit wiki, no student athlete ever posted no matter how much the extra credit could have raised their grade. These classes are dominated by African-American males who tend not to post online even if credit is attached. This possibly influences all of the students? In the entirely online sections it appears that even those students who could have used the extra points to improve their grade (ex. From a D+ to a C-) would avoid the voluntary board if the posting pattern did not fit their idea of what should be there. In the same situation in the required board, males would simply post the minimum required and females were more likely to become chatty. Undergraduates however do not seem to be discouraged by discussion board posts that don't fit their ideas about what should be there. They do not contemplate dropping or at least do not ask the instructor if they should drop based on the nature of discussion board or wiki communication. Undergraduates tend to post in the style they choose.

The majority of undergraduate students have been born digital and conventional wisdom seems to be that they should be comfortable with whatever style posts others make and should be comfortable posting in the style they prefer. This however does not seem to be the case. Chattiness in online discussions seems to be off putting to undergraduate males. Undergraduate females seem to be less affected by more technical or straight forward posts by males than graduate females seem to be. Student athletes seem to be reluctant to post online at all. This may be due to issues stemming from ethnicity as seems to be the case during live discussions or may be due to other factors yet to be determined.

What we have discovered so far does lead the authors to be able to draw at least one very important conclusion respecting the structuring of undergraduate online communication. The conclusion must be that a significant percentage of students cannot at present be depended upon to post to class discussion boards, wikis or any other type of online communication platform. Therefore it is best not to put too heavy an emphasis on them as a credit bearing part of the course. However that does not mean that instructors should abandon these tools altogether. Instructors must strive to determine how to foster more responses, perhaps through the use of tools that seem 
Implications of Voluntary Communication

less like "school work," such as skype, twitter, instagram and others similar communication mediums still being developed.

\section{Overall Conclusions}

Communication is the key to creating the social networks that graduate students need to develop to be successful in their chosen career. Distance education runs the risk of creating isolated students who become isolated professionals and thus missing one of the key factors for satisfaction and success in their job. Initial postings seem to be very important with voluntary discussion in terms of male participation.

Although the sample of classes studied here is far too small to make any sweeping generalizations, it may be that the next generation of librarians is as comfortable or more with text communication than voice. The popularity of text messaging via the cellular telephone and Instant Messaging through an Internet provided like America Online may have an influence on the communication preferences of today's college students. Such preferences will need to be considered when designing curriculum and classes for these students. Obviously, providing the right communication tools is important in distance education to allow students to develop social networks with other students despite geographical boundaries. Additional research is needed in order to determine the right mix of communication tools needed.

\section{References}

Burnett, G. (2000). Information exchange in virtual communities: A typology. Information Research, 5 , 536-537.

Gefen, D., \& Ridings, C. (2005). If you spoke as she does, Sir, instead of the way you do: A sociolinguistics perspective of gender differences in virtual communities. The Database for Advances in Information Systems, 36(2), 78-92.

Gregory, V., \& Cox, K. (2006). Gender and cultural differences in communication preferences in graduate education. International Journal of the Interdisciplinary Social Sciences, 1(3), 79-84. Retrieved from http://iji.cgpublisher.com/product/pub.88/prod.53

Herring, S. (1996). Bringing familiar baggage to the new frontier: Gender differences in computermediated communication. In V. Vitanza (Ed.), CyberReader (pp. 144-154). Boston, MA: Allyn \& Bacon.

Herring, S. (2000). Gender differences in CMC: Findings and implications. CPSR Newsletter, 18. Retrieved from http://cpsr.org/issues/womenintech/herring/

Kling, R. (2000). Learning about information technologies and social change: The contributions of social informatics. The Information Society, 16, 217-232. Retrieved from http://www.dlib.org/dlib/january99/kling/01kling.html

Kling, R. (2000). Learning about information technologies and social change: The contributions of social informatics. The Information Society, 16, 217-232.

Tannen, D. (1994). Talking from 9 to 5: Women and men at work. New York, NY: William Morrow.

Tannen, D. (1995). The power of talk: Who gets heard and why. Harvard Business Review, 73, 5.

Van House, N. (2004). Science and technology studies and information studies. In B. Cronin (Ed.), Annual Review of Information Science and Technology (pp. 3-86). Medford, NJ: ASIS\&T by Information Today.

Wajcman, J. (2010). Feminist theories of technology. Cambridge Journal of Economics, 34(1), 143-152. 
Yates, S. (1996). Oral and written linguistic aspects of computer conferencing: A Ccrpus based study. In S. Herring (Ed.), Computer-Mediated Communication: Linguistic, Social and Cross Cultural Perspectives (pp. 29-46). Amsterdam, The Netherlands: John Benjamins.

Yates, S. (1997). Gender, identity and CMC. Journal of Computer Assisted Learning, 13(4), 281-290.

\section{Biographies}

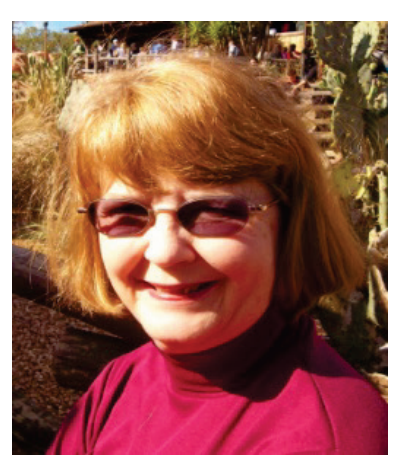

Vicki L. Gregory is a Professor in the School of Information at the University of South Florida, where she served as Director from 19992007. Her teaching is in the areas of Collection Development, Digital Libraries, and Information Retrieval. She holds an M.A. (History) and an M.L.S..(Library Services) from the University of Alabama and a $\mathrm{Ph} . \mathrm{D}$. in Communication, Information and Libraries Studies from Rutgers University. The author of several books, including Collection Development and Management for Twenty-First Century Libraries, recently published by Neal-Schuman/ALA, she was formerly Chair of the American Library Association Committee on Accreditation, and is currently a member of the Board of Directors and Treasurer of the Association for Information Science and Technology (ASIST).

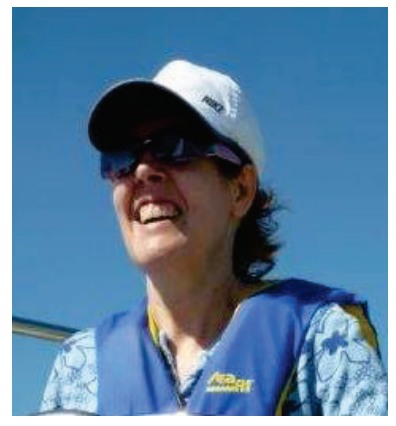

Kiersten Cox holds a Master in Library and Information Science degree from the University of Hawai'i and a Master of Arts in International Affairs from Ohio University. She spent many years as a librarian in a variety of settings. She was a research assistant for a Fulbright Scholar which allowed her to live in Indonesia and the Netherlands. She has been teaching in the School of Information at the University of South Florida for over ten years specializing in teaching information literacy skills to students in an online environment. 